EDITORIAL

\title{
Breaking the chains: Strategies to overcome poverty in Colombia
}

\section{Silvia E. Campuzano Fernández ${ }^{1}$, Andrea M. Turriago Campuzano², Gloria M. Cortés Saavedra ${ }^{3}$}

\begin{abstract}
1. MSc Microbiología, U. Colegio Mayor de Cundinamarca, Líder Grupo Bazeri.
2. Finanzas y Relaciones Internacioales, U. Externado de Colombia, Grupo Bazeri. 3. MSc en Planeación Urbana. U. Santo Tomás de Aquino.
\end{abstract}

$\mathrm{P}$ overty in Colombia denotes the serious problem of inequality distribution of income, characterized by some of the most terrible poverty statistics in Latin America. For this reason, the Colombian government and the private organizations especially the economic ones, both have been working in reducing the poverty problem, by the introducing of charity programs with poor outcomes that become superficial solutions, due to the effects on the economy of social, political and economic events throughout the history of the country, and the effect of armed conflict, that do not allow them to advance in the results.

Moreover, the poverty in Colombia has been determinate lack of human basic necessities, which are demonstrate in a lot of problems such as illiteracy, malnutrition, short time of life, bad mother's health and sufferings for diseases that could be easily treated. This type of approach is called: "the human poverty", which focus in what the people can or cannot do, but does not focus in what the people have or do not have.

An indirect way of measuring it is through the access to goods, services and infrastructure such as: energy, education, communications, drinkable water, among others, that are necessary for the human beings to develop their selves properly, and in the same way their basic capacities. The different quantities of goods and services that poor people have and the access they have to them, allows to determinate in which level of poverty they are; the problem with this approach takes root in determining what type of goods and services must be selected, however, the determination of this type of necessities, gives a good idea of their scant resources, which place them in this situation of severe income disparities and inadequate social services.

Organizations such as the World Bank estimates that $65 \%$ of the population, live below the poverty line and rural poverty is especially acute and serious. The rural workers in Colombia are estimated in the poverty rate in $80 \%$, of which $42 \%$ is considered extreme. In addition, only $15 \%$ of rural dwellers have access to telephone services, $62 \%$ to drinkable water, and $32 \%$ to sewage treatment services.

Other organizations such as the Latin American Center of Rural Development had concluded that 8 of the 11 countries (Bolivia, Brazil, Chile, Colombia, Ecuador, El Salvador, Guatemala, Honduras, México, Nicaragua y Peru) included in their projects, have poverty mapping activities of one or other form, but, who has one of the most highest poverty mapping activities is Colombia. ${ }^{1}$.

The information before, gives an idea of the Colombians poor conditions that are worst in rural areas by a $15 \%$ illiteracy rate. World Bank studies also show, that Colombia will require an important economic growth of $4 \%$ through 2010 to reduce poverty to the levels recorded in 1995 . This is especially challenging considering that the Uribe's Government

1 Rimisp - Latin American Center for Rural Development is a regional non-profit organization that was set up in 1986. Latin American rural development, understood as strengthening the capacity of different social groups in the rural sector, and enhancing the freedoms enjoyed by the people who make up rural society in our region. The organization is committed to supporting those who are marginalized and excluded within rural societies. However, it does not seek to represent such people or speak in their name or that of any other social sector. Rimisp's legitimacy is founded on its organizational culture, its work and on the extent and type of relationships it has with its partners. 
has reduced fiscal spending and that foreign direct investment in 2002 has diminished under $\$ 2$ billion, a melt off of about a half compared with middle 1990s.

Moreover, lack of state presence in strategic places of the country, has allowed illegal narcotics production and armed, drug-dealing, and terrorist organizations which try to prevent and to end the conflict, but they can't. While Colombia's illegal armed groups have been weakened, their presence and ability to inflict violence against the state and civilians continues.

There are different methods to measure the level of poverty in the world, but this one is measure in Colombia by a common method based on incomes or consumption levels. A person is considered poor if his or her consumption or income level, falls below some minimum level necessary to meet basic needs. This minimum level is usually called the "poverty line", that vary in time and place, and each country uses lines which are appropriate to its level of development, societal norms and values. Most people in Colombia, lives below the poverty line because they don't have how to satisfy their basic needs varies.

This kind of information on consumption and income, is obtained through sample surveys, with which households are asked to answer some questions about their spending habits and sources of income. Such surveys are conducted regularly in Colombia, because these sample survey data collection methods allows government to understand the people situation by asking them which their basic needs are and what poverty means for them and in this way, create new programmes to solve their well - development problems.

There is another method to measure the poverty level, by looking the Human Development Index created by the United Nations Development Programme - UNDP. The Human Development Index is defined as the arithmetical average of the achievements of a country in three basic dimensions of the human development: longevity (life expectancy), level of education: rate of literacy of the adult population, combined with the rate of matriculation in the elementary, secondary and tertiary education and standard of living. The Human Development index, vary from zero (0) to one (1).

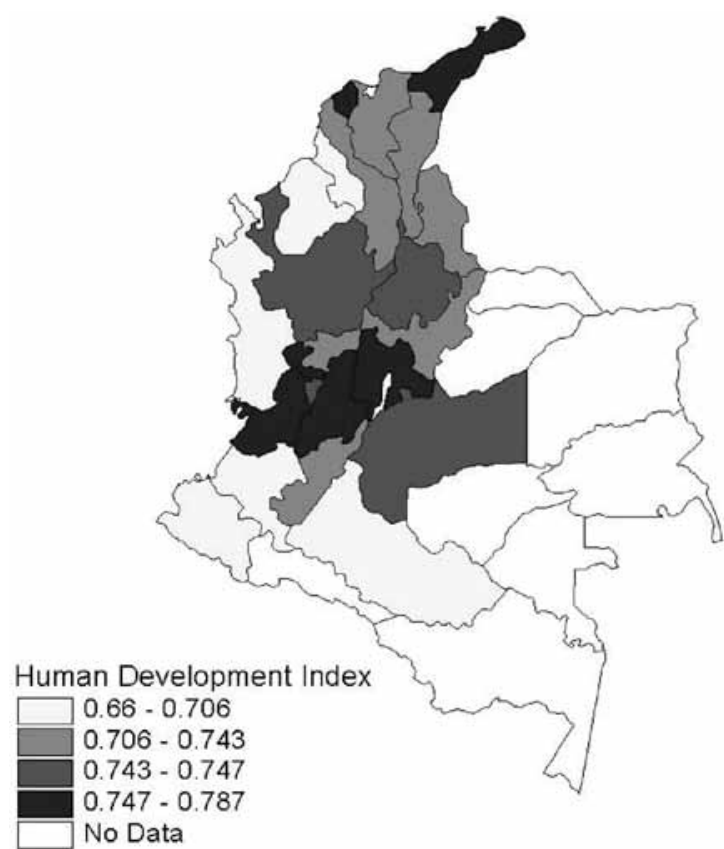

Map of Colombia Human Development Index. The map shows Human Development Index in Colombia in 1999. In different greens it explain the poverty degree of the departments in Colombia. Near 0: Lower Human Development

Near 1: Higher Human Development

Provided by: http://earthtrends.wri.org/povlinks/country/colombia.php

The human development index trends tell an important story in that respect. Between 1980 and 2007 Colombia's HDI rose by $0.59 \%$ annually from 0.688 to 0.807 today. HDI scores in all regions have increased progressively over the years, although all have experienced periods of slower growth or even reversals.

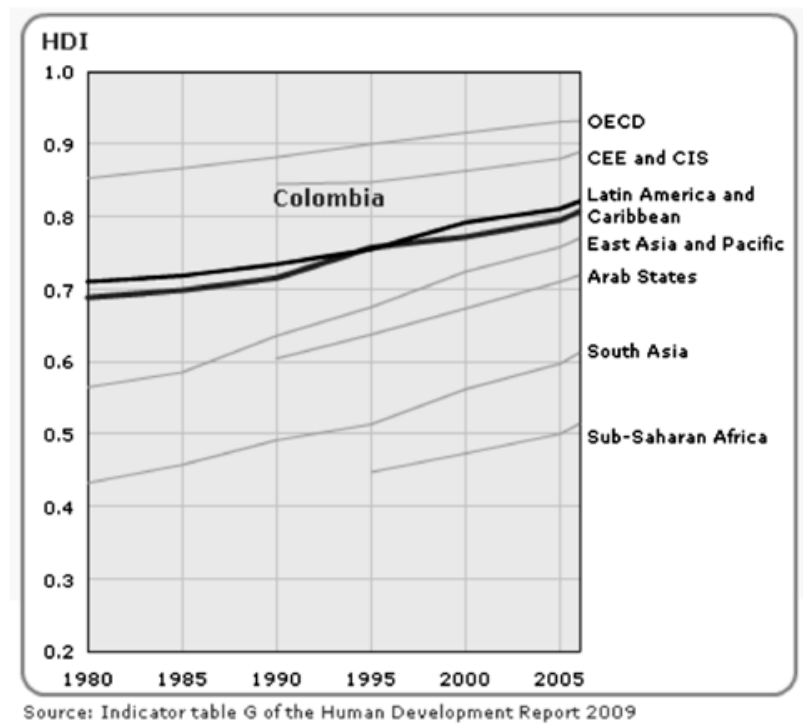

HDI Trends. Source: Indicator table G of the Human Development Expert 2009, http://hdr.undp.org/en/statistics/ 
This year's HDI, which refers to 2007, highlights the very large gaps in well-being and life chances that continue to divide our increasingly interconnected world. The HDI for Colombia is 0.807 , which gives the country a rank of $77^{\text {th }}$ out of 182 countries with data.

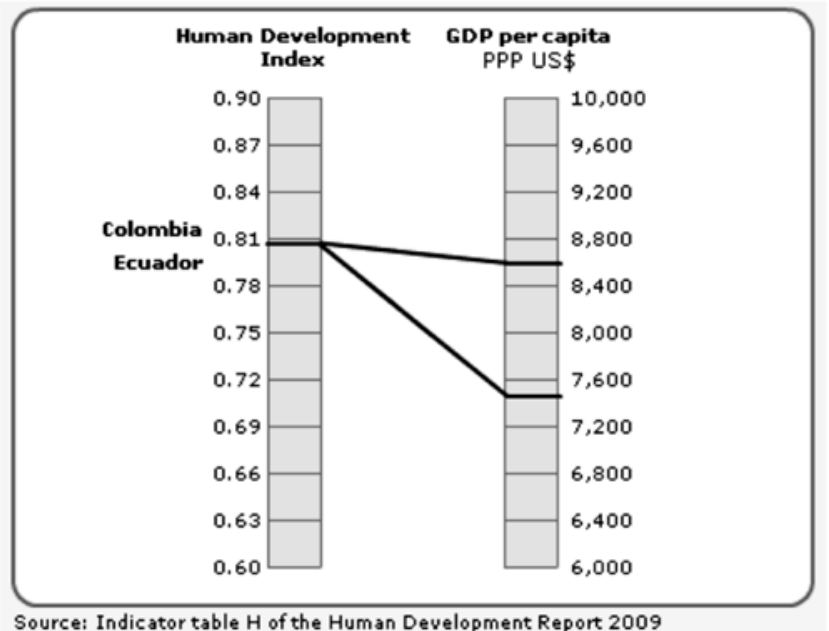

Source: http://hdr.undp.org/en/statistics/

The figure below illustrates that countries on the same level of HDI can have very different levels of income or that countries with similar levels of income can have very different HDIs. The human development index gives a more complete picture than income.

By looking at some of the most fundamental aspects of people's lives and opportunities the HDI provides a much more complete picture of a country's development than other indicators, such as GDP per capita, Table 1.

\section{Economic Solutions for Poverty in Colombia}

The reduction of the poverty is the fundamental task with which the world community meets confronted, and there is an important debate around the policies that might help to reach this purpose and the way in which the financial international institutions might endorse the companies.

The poverty can be reduce stimulating the growth of the GDP per capita, increasing the whole resources the population can have, and increasing the percentage of these resources that goes to the poorest sectors. In this way, the economic growth can be stimulated through government policies directed to promote the macroeconomic stability such as: low and stale rates of inflation, limited deficit budget and a viable foreign debt. Also, the opening to international trades, the education and the empire of the law, could act as stability policies to increase the Colombian GDP per capita.

International and regional organizations are worried about the poverty rates in Latin America but especially in Colombia. All of them try to give their best in the war against poverty.

The CEPAL gives services of researching, studying and other activities of support, promotes the economic and social development through cooperation and the integration to regional and subregional level. In addition, interprets and spreads information relative to the economic and social development of the region, gives services of advice to the governments by request of these and plans. The CEPAl had been organizating and executing programs of technical cooperation in Colombia.

\begin{tabular}{|c|c|c|c|c|}
\hline HDI value & $\begin{array}{l}\text { Life expectancy at birth } \\
\text { (years) }\end{array}$ & $\begin{array}{c}\text { Adult literacy rate } \\
\text { (\% ages } 15 \text { and above) }\end{array}$ & $\begin{array}{c}\text { Combined gross enrolment } \\
\text { ratio } \\
(\%)\end{array}$ & $\begin{array}{l}\text { GDP per capita } \\
\text { (PPP US\$) }\end{array}$ \\
\hline 1. Norway $(0.971)$ & 1. Japan (82.7) & 1. Georgia (100.0) & 1. Australia (114.2) & 1. Liechtenstein $(85,382)$ \\
\hline 75. Brazil (0.813) & 71. Estonia (72.9) & 57. Qatar (93.1) & 59. Mongolia (79.2) & 79. Brazil (9,567) \\
\hline $\begin{array}{l}\text { 76. Bosnia and Herzegovina } \\
(0.812)\end{array}$ & 72. China (72.9) & 58. Mexico (92.8) & 60. Romania (79.2) & $\begin{array}{l}\text { 80. The former Yugoslav } \\
\text { Republic of Macedonia }(9,096)\end{array}$ \\
\hline 77. Colombia (0.807) & 73. Colombia (72.7) & 59. Colombia (92.7) & 61. Colombia (79.0) & 81. Colombia $(8,587)$ \\
\hline 78. Peru (0.806) & 74. Nicaragua (72.7) & 60. Malta (92.4) & 62. Jordan (78.7) & 82. Thailand $(8,135)$ \\
\hline 79. Turkey $(0.806)$ & 75. Saudi Arabia (72.7) & 61. Indonesia (92.0) & 63. Saudi Arabia (78.5) & 83. Dominica $(7,893)$ \\
\hline 182. Niger $(0.340)$ & 176. Afghanistan (43.6) & 151. Mali (26.2) & 177. Djibouti (25.5) & $\begin{array}{l}\text { 181. Congo (Democratic } \\
\text { Republic of the) (298) }\end{array}$ \\
\hline
\end{tabular}

Table 1. Source: http://hdr.undp.org/en/statistics/ 
The Inter - American Development Bank IDB by his Social Policy Monitoring Network had been improving the ability of Latin American and Caribbean countries to evaluate the impact of social policies and to improve the design of policies in social areas. By joining experts and regional researchers interested in evaluation and policymakers from social ministries and agencies, the network focus on:

- Promoting the value of evaluation.

- Expanding the understanding of the effects of social policies.

- Building technical capacity to evaluate and design social policy.

The Organization of American States OAS had been working on regional cooperation and advancing in common interests, through multilateral dialogue forums. The OAS have diverse units and departments which deals with issues such as: inequality, education and culture.

The World Bank Group WBG had been providing loans, policy advice, technical assistance and knowledge sharing services to low and middle income countries like Colombia, to reduce poverty. It is consider the world's largest external source of funding for education programs.

Multilateral assistance to Colombia from the World Bank, Inter-American Development Bank, the European Union, United Nations agencies, the Andean Development Corporation and others, totaled $\$ 49.9$ million in 2002. Other bilateral development assistance to Colombia reached roughly $\$ 65$ million in 2002 with Germany, Spain, and the Netherlands the most significant contributors.

The USAID Program had been creating economic opportunities and providing assistance to the internally displaced. USAID's strategy in Colombia, supports President Uribe's Democratic Security Policy, which consolidate the rule of law and defend and strengthen democratic institutions throughout the country.

The USAID program has three objectives:

1. Stem the flow of illegal by encouraging small producers to join the legal economy through licit economic activities and infrastructure projects.
2. Promote more participatory, responsive, and accountable democracy

3. Relieve the plight of Colombian refugees.

Colombia's government had announced a new plan to address economic suffering in a country where nearly $50 \%$ of the population live below the poverty line. Since President Alvaro Uribe Velez took office in 2002, he has worked to establish state control throughout the country, increase the level of the Colombian economy, and fight against corruption. Colombia's ranking in the Transparency International Corruption index improved 17\% between 2000 and 2003, the highest among the more than 40 medium and low-income countries.

The Government of Colombia have been working with the USAID Program in the management of a $\$ 45$ million fund created by the Enterprise for the Americas, that forgives foreign debt in exchange for environmental and child protection initiatives. Also, promotes democracy, conflict prevention and humanitarian assistance through health programs.

The Director of the National Planning, Carolina Renteria, said that they will work with international organizations to focus on the challenge by introducing a specific plan against poverty. The goal is to reduce the rate of people living below the poverty line from $50 \%$ to $39 \%$ y 2010 , and those living in extreme poverty from $14.7 \%$ to $8 \%$ by that same year.

\section{“The government's principal objectives will be to construct an economic, social and institutional strategy that applies the majority of the labour force as the principal engine for economic growth and equality"}

On the base of comparative studies of diverse countries, it is known today that the economic growth is linked to the improvement of the indicators of the well-being. The compilations of information that have been carried out to remedy this deficiency, might contribute in an important way to our knowledge of the links among the macroeconomic policies and the reduction of the poverty.

In this framework, it is important to focus strategies on enhancing quality of life for people through 
the relationship between government and rural vulnerable areas of the country, by the introducing of public services such as drinkable water, healthiness, garbage collection and management, and so one; in order to break the geographic limits, because the ones who really need governmental investment, are the ones who are the most unprotected.

On the way of solving this issue, an excellent idea should be, opening sme's to national strategic programs, to help them to be able to answer the necessities of the poorest countries, in their requirement of preventing people from diseases, which could damage health care of the poor people as a consequence of environmental contamination; through the strengthening support to sme's, providing easier credits by Colombian banks who should grant low credit rates, long time for credit payment and flexible requirements.

In consequence the results of this strategies would develop in a new economic driving force, that would generate: more opportunities of employment, new entrepreneurs, new business, promote strength economic sectors which could be more competitive for stimulating the productivity.

Likewise, the environmental conditions have an incidence in the society's poverty, due to the negative environmental impacts such as: climate changes, earthquakes, between others. In consequence, the study of the relationship between environment and poverty, results to be an important affair.

\section{Environment and the influence of the poverty}

The deep analysis of the conditions that somehow, influence the deterioration of the environment, extracts afloat the indexes of poverty of the environment, as a factor of risk for the implementation of the healthy politics for the sustainable development in the processes of production.

It is an integral responsibility, to show to the community that the industrialization can be met in harmony on the education, the health, the safety and the environment to achieve the sustainable development understood as, the one that leads to the economic development, to increase of the quality of life and to the social well-being, without exhausting the base of the natural resources in which it is sustained, not spoiling the environment or the right of the future generations to use it for the satisfaction of their own needs.

So that, encouraging measurements to a business ethical spirit, where there is awaited a major efficiency of the industrial processes, the organization of preventive strategies, the incorporation of technologies and clean procedures of production along the cycle of life of the product, so that they diminish to the minimum or the avoided wastes, reducing in the same way, the negative consequences in the utilization of the resources and the environment. Consequently, it is achieved to control somehow the conditions of poverty which concerns to the countries in process of development.

The humanity already cannot survive without the technical skills. The technology can lead to fatal consequences like ecological deterioration and the exhaustion of natural resources. The commerce and the industry, included the transnational companies, perform a crucial function in the economic models that prevail in countries such as Colombia.

Many of the businessmen work in a slightly responsible way because of the laxity in the procedure and the lack of institutional serious and deep criteria. It is possible to say that such circumstances are ideal in order to prosper business slightly ethical conducts. It makes furthermore, necessary a regime of stable policies that stimulates the commerce and a few forms of functioning responsible for the industry.

The decentralization of industries that is equivalent to the location of the processes of higher risk out of the borders of the industrialized countries, they are typical of the processes of globalization that are lived nowadays. The industrialization of the rural spaces, the pressure on new fountains of natural resources (Ex; waters), as well as the new location of the companies will be depending less by the distance and more of the scanty resources as water, energy, among others.

That is, the goals in relation to the policy of management of the solid residues, must reflect the practice of cleaner production that allows a sustainable development assuring the environmental cleaning, actions that are not exploited or apply under a scheme constructed in different companies and institutions. 
It has been determined that the technological development, can be one of the strategies used to attack the levels of poverty of a community, in the sense that will generate sources to work on and simultaneously work of good quality, with exigency of the current world to answer to the conditions of the globalization.

It wants to begin to compete with quality and efficiency on the common markets and there has been verified that it is better to offer productions that are amicable to the environment, which they are profitable and which avoid subsequent expenses of recovery of fundamental elements for the quality of life, such as the health, the healthy environment, the control of the pollution and other conditions of deterioration that are of difficult managing once they have taken place.

According to new technologies, they has been developing diverse researches in the area of physical and biological treatment. For the first case, it arranges with diverse techniques of treatment for the obtaining material that can change to solid with a minimal addition of constituent others. For the biological treatment, there are investigations about the biological valuation, biodegradation compounds of organochlorine, such as the lindane, DDT and 4, 5, 6 - trichlorofenol, across microorganisms that have capacity of being biodegraded.

In the most hygienic national center of production (Costa Rica) it has been found that the evaluations in plant are perform in the industrial installations in order to identify options of cleaner production clean and to promote this strategy and the minimization of wastes in the companies. The companies will be able to see their saving and to improve in efficiency to be more competitive and sustainable, with a vision to the future. The commitment of the company is necessary through the management office by policies of reduction of the pollution, the assignment of people who can observe and share their results.

From the contribution that is expected from the industry in any level, it is necessary to teach the managing of cleaner production, which assures environments, and then this method is based on the process evaluation that involve 5 stages:
- Stage 1 . To recognize the need to prevent the pollution, using cleaner production.

- Stage 2. Planning and organization: To obtain commitment of the management. To establish the organization of the evaluation. To propose general objectives. To overcome barriers. To initiate preliminary study.

- Stage 3. Evaluation: Information of company and her processes. Flows of materials, waste and emissions. (Teams work). To generate options of cleaner production.

- Stage 4. Analysis of feasibility: Technical evaluation. Economic evaluation. Environmental evaluation. Selection of options.

- Stage 5. Implementation: Fund raising. Installation of equipment. Monitoring and evaluation of results. Adjustment of the project. Planning new projects.

It is a constant strategy inside the companies, that new productive processes that could be optimize, appear after the implementation of new opportunities.

As the technological development has advanced in the managing of dangerous residues and there have been introduced laws that prohibit the unload of toxic or dangerous pollutants to the environment, the managing of dangerous residues a significant cost has acquired for the industry in the developed countries. This factor, besides the fact of which the industry meets, increasingly, obliged to preserve the natural resources and the energy, it is promoting the creation of industrial alternative technologies for the reduction of generation of residues.

Since 70's it is observe that the development of the technology of minimization of industrial residues, advances and spreads in the current decade. The minimization of residues is achieved across the optimization of the industrial processes and of the recycling of the generated residues.

The recycling can be executed inside the same industrial plant or out of her depending on the utility that could be give to the residues. The recycling of solid and liquid residues can be perform directly or after an intermediate treatment. Examples of this are the reuse 
of the liquors of chrome in the tanneries with a simple interval sifted interval (6), and the recovery of heavy metals of the worn-out baths of end of metals, through the rainfall and separation of the precipitate. (10)

In Colombia to face the problematic, there have been adopted governmental strategies (DAMA. Ministry of Environment) with programs of environmental health and normalizations related to the managing of residues or wastes in order to manage the goal of controlling the industrial residues in sure form allowing the industrial development in harmony with the environment. (4)

The criterion of cleaner production, as a way towards the sustainability of the companies, could not be reduce to the hard technologies, but it must include all the administrative and organizational strategies of the companies. It is not possible to speak about cleaner production in companies where an inhuman exploitation of the workforce and where there are no criterions of equity for with the workers. Equally, it is necessary that the employers could take voluntary, not coercive initiatives, for which they promote and apply self-controls and assume major responsibilities In order to try to take care of the repercussions of their activities in the human health and the environment.

Precisely, like response to all this problematic, arises the system of environmental management that involves the creation of a space, which the objects of physical study natural and socio -cultural must be approached in a joint way and must explain in an analytically way the environmental phenomena with sufficient conceptualizations for the capture of decisions of management and to answer to such aims as the prediction, prevention, mitigation and compensation of the impacts on the environment, the frame of the sustainable development.

The environmental coherent management, arises of an operative way and in permanent process of improvement, to be supported in a set of principles that guides it in a solid way, they are:

Responsibility

This principle gives response to the need of a sustainable development. The present generations are persons in charge of delivering a world to the future generations where there is possible the existence of a global ecosystem with levels supported of biodiversity, a human existence with increasing levels of public health, the development of the economic activities and the capital of both physical and biological resources that is characterized by the richness and variety of options. Integral

The environmental planning deals with the interrelationships between a human given activity and the environment. Therefore it studies the physical, biological and social components of such interrelationships, understanding that only bearing in mind the contribution of several branches of the knowledge, it can come near to the conception of the environment as the quite unified one.

\section{Quantification}

One of the purposes of the environmental management in all that disciplines in process of development is the quantification of the entities with which it works and which train the object of study.

\section{Applicability}

The purpose of the environmental management is the managing of the environmental impacts in a few given conditions; therefore the acquisition of information, the conception and accomplishment of the studies, the selection of criteria for the evaluation, must be guided by the applicability of the results.

\section{Optimization}

Realizing any activity of the environmental management, this one must be carried out bearing in mind that designing is optimizing, and therefore the effort of conceptualization to must remove up to the point where not only one solution is proposed, but this one must be ideal from the optics of some criterion.

\section{Aims of a system of environmental management}

- To orientate the diagnosis of the environmental current situation of a certain area and to identify projects of management with action strategies to face the identified problematic.

- To qualify the community leaders and civil servants of institutions in the program of Environmental Education.

- To define the mechanisms for conciliation and 
coordination of own actions of the Program of Environmental Education among the community and the public and private organizations.

- To stimulate the coordination and interinstitutional cooperation.

- To guarantee the community participation. (3) In order to overcome the negative impacts of the environmental contamination, exists an instrument which is considered as the most helpful to change people's attitude, in their necessity of managing the self-care culture and furthermore try to avoid the contamination to the environment. This strategy is the education. The interest of this document revolved around the ways for teaching the SME's in the adequate management of the waste materials through education, by giving to businessmen innovative strategies and processes to manage them, and to help them understanding their importance in the reduction of poverty and respect for the nature.

\section{Education solutions for poverty in Colombia}

In the work of the German philosopher Sloterdijk, P. (2005), the life develops since different aspects, and what it defines to the modernity, is the joint faint of poverty and reality. In his book "You" Foam"the author describes the process of the modernity as a process of anti gravitation, it is said to the technical inventions that they allow to the men to conquer the space and to fly in the air, but, in a more general way, expresses that: "the life has lost much of his gravity what means both his load of poverty, pain or hardness and his load of ontological reality ". Vasquez (2008).

Our "opulent society" is definitively liberated of what the author calls "the definitions of the reality formulated by the ontology of the poverty ", we stick to the formulae and express the absence of misery and the gravit absence in these two languages."This means that the social recovery of nowadays just can mean or the hypocritical attempt of masking the reality of the abundance or the desire of more abundance ". Vasquez, (2008)

From the epistemology and the sociology the topic in question, it is acquired a specific connotation, which expresses for a sharp crisis of the current society, characterized by poles and interests significantly objected in the social thing, economic and environmental politician; community devoid of unit of thought, in what to the entity of the ethical thing - moral and ontological, it refers; lack, which has turned her, in a theoretical place of discussion, between connoted thinkers and, nevertheless the developments reached as for the concretion of conceptual benevolent positions with the nature, still ways of learning are absent for crossing in the set of nations that shape the terrestrial globe.

Partly, the raised problem, it is a product of the "process cultural associate" that corresponded to us to live and referred in the middle of the 19th century based on the secularism, which it orientates to the modernity, influenced by the ideas of freedom and progress of the French illuminists, with the denial of the wisdom and divine origin of the creation, devoid of values, virtues and humanitarian attitudes with live naturally and socially. Ideal stage for the development of the following perverse attitude, with serious consequences and repercussions for the present and future generations; "The Man has the reason and is the owner of the world", and "The Man supported by the technology and the technology is self-sufficient". ${ }^{2}$

So, the instrumental rationalism, in term of efficiency, efficacy and become effective to obtain the awaited results, bosses and legal procedures of behavior, utilitarian in the economic, commanding of the capitalist system, with ends and a half of reproduction accelerated, is constituted in the paradigm that guides the conduct of the communities; without warning the serious consequences that would have, for the development of the life, the ignorance and the indiscriminate use of the manners, methods of production and intensive reproduction of the capital; in detriment and degradation of the right to the life, of a set of alive beings, who inhabit and share the ecosystem.

\footnotetext{
2 According to Marcuse "the technological at the beginning is a political idea, while the transformation of the nature implies that of the man, and the creations of the man are given around a social set. The machinery of the technological universe is not indifferent to the political area, moves to the pace that this imposes him." Vásquez, (2008).
} 
One denies the natural and social right, of enjoying a physical environment - nicely and healthily for the delight and well-being of the Man. This position is validated by the positivism, conception that it considers: "that so much the human beings", since "not human beings", they are only objects, things that produces quantity and, therefore, this way they must be treated. In addition, it favored, the model of economic growth, where the model of development is absent sustainable, that agency the well-being and the happiness of the social group.

The vision of the problem is critical and significant simultaneously, for his scopes and transcendence opposite to the observed reality. Present is had that the ecosystem, beside he constitutes, according to his logical and natural order, the biological the physical and chemistry, is a social category, recreated artistically with wisdom, with solid foundations, own(proper) values, knowledge, attitudes and manners of behaving, to take place(be produced) and to be reproduced; in the area of a non-existent rationality cultural associate and politics(policy), which precisely for his significance and significance (meaning) will allow that of his observation and comprehension, educations and learning could be extracted of and for the life.

The union between physical and social space, has limited herself to establishing standards extracted from the economic and technological politics(policy) of environmental universal, national and regional managing, leaving of side the social conflict of the country, in the area of the political thing, which is where the problem is located; managing and exploitation(development) of natural resources, including minerals, petroleum wells and other resources of potential ecological and economic high place; are observed strategic regions surrounded by suburbs of extreme poverty.

There is demonstrated, that the environmental problem more that to be a problem of to know ecologically, it is an epistemology and sociological problem, that it concerns, undoubtedly, the set of fields of the knowledge; in economy, there is demonstrated the disability of the analysis to visualize the problem of the cost of the externalities, or external positive or negative effects, depending on the interdependence and their areas of action, provided that the problem is not an exclusive matter of market and of prices, in addition because it is a question of a "giant without control", with the highest economic activity impossible to measure in his effects and consequences, as well as in his prevention.

There competes(stations) to a rationality environmental, cultural associate, organic, spatial significant in the context of the development sustainable, with values, social and political processes, which exceed the current structures and integrate to know of interdisciplinary form, to re-elaborate the conceptual frames, categories and procedural and methodological instruments, which allow the construction and integration of the knowledge, in favor of ecological attitudes, change transformer that generates conscience of the auto care and the auto management in the area of the biological and cultural biodiversity, we must construct culture, educate and demonstrate that it is only by means of the human intervention that is achieved to respect inhabit. ${ }^{3}$

It is required to work to offer that they should include public politics of environmental democratization. The base is the "productive rationality been founded on the socialization of the natural and cultural means of production "Leff 1998:340.

Education is and will always be a key factor in the success of people from all backgrounds. It provides children with greater opportunities and offers a better perspective on life. Most importantly, it can be the breaking point out of the poverty cycle which affects hundreds of families in Latin America and around the world. A poor person with a good education has the opportunities to escape from poverty in ways that an uneducated person can never hope for. Education is the solution for many social problems and increased education has even been shown to decrease delinquency and violence.

\footnotetext{
3 In the frame of the social rationality defined to the style Weberiano, there are foreseen the rules and structures that orientate the social practice and live together in an inseparable way, define the instruments of development with ethical effects and bosses of production, emphasizing a rational action in accordance with ends, values, affective actions.
} 


\section{Bibliography}

1. ARIAS D, Alberto. Inventario y estado de los Recursos Naturales y del Medio Ambiente Pereira: Proyectos y Estrategias LTDA; 1994

2. Boletín Epidemiológico Distrital. Vol 1, ejemplar 11. Octubre 13-26 d3 1996.

3. Boltanski, Luc y Chiapello, Eve. (2002).El nuevo espíritu del capitalismo. Ed. Akal. Madrid.

4. Baumol, William \& Oates, Wallace (1975). The use of standards and prices for the protection of the Enviromental policy externalities, public outlays and the quality of life, Prentice Hall.

5. Confederación Latinoamericana De Bioquímica Clínica. Mejoría Continua de la calidad. Médica Panamericana.México;1995.314p

6. Corporación Autónoma Regional De Cundinamarca. Educación para la gestión ambiental. Santafé de Bogotá: CAR; 1994. 80 p

7. Colombia Poverty and Wealth, Encyclopedia of the Nations. http:// www.nationsencyclopedia.com/economies/Americas/ColombiaPOVERTY-AND-WEALTH.html

8. Colombia Medical - Inequity, Poverty and health http://www.scielo. org.co/scielo.php?pid=S1657-95342006000300009\&script=sci_arttext

9. DAMA, Resolución 1074.Santafé de Bogotá: DAMA, 1997.12p

10. Earth Trends $\rightarrow$ http://earthtrends.wri.org/povlinks/country/colombia.php

11. HUNT, David. JOHNSON, C. Sistemas de Gestión Ambiental. Mc Graw Hill. Madrid, 1996. 318 p.

12. IDEM. Impacto de los residuos industriales, salud de los trabajadores y medio ambiente, 1997.

13. Instituto Colombiano De Normas Técnicas. Catálogo. División Publicaciones. ICONTEC, Santafé de Bogotá, 1999.

14. Instituto Colombiano De Normas Técnicas. Guía Técnica Colombiana 24, ICONTEC, Santafé de Bogotá, 1999. 9p.

15. Instituto Colombiano De Normas Técnicas. guía técnica colombiana 53-3, ICONTEC, SantaFé de bogotá,1998. 9 p

16. Instituto Colombiano De Normas Técnicas. Sistema de gestión ambiental ISO 14000. Formación en sistemas de administración ambiental. ICONTEC, Santafé de Bogotá,1996. 86 p.

17. Instituto Colombiano De Normas Técnicas. Conceptos básicos y fundamentación ISO 9000.Formación básica para operar sistemas de calidad. ICONTEC, Santafé de Bogotá,1996. 85 p.

18. IMF: http://www.imf.org/external/pubs/ft/fandd/spa/2001/06/pdf/ cashin.pdf
19. Leff, Enrique (1994). Sociologia y ambiente: Formación socioeconómica, racionalidad ambiental y transformaciones del conocimiento en "Ciencias Sociales y formación ambiental, GEDISA", red de Formación Ambiental para América Latina y el Caribe, UNAM, Madrid.

20. Leff, Enrique (2000). Pensar en la complejidad ambiental: La complejidad ambiental, siglo XXI, Centro de Investigaciones Interdisciplinarias en Ciencias y Humanidades, UNAM, PNUMA, México.

21. Manual De Acreditación Para Instituciones Hospitalarias-Colombia. Ministerio de salud, Superintendencia Nacional de Salud, OPS - OMS, Instituto de Seguros Sociales, Asociación Colombiana de Hospitales y Clínicas, asociación Colombiana de facultades de Medicina. Santafé de Bogotá, 1995

22. Ministerio Del Medio Ambiente. Normas para la Protección y la Calidad del aire. Santafé de Bogotá: Ministerio del Medio AmbienteDAMA; 1995.

23. Ontario Environmental and safety Network: http://www.oesn.net/

24. OFFSTEIN, NORMAN,. National, departmental and municipal rural agricultural land distribution in Colombia: analyzing the web of inequality, poverty and violence. Documentos CEDE, Bogotá. No. 37. Junio 2005. Universidad de los Andes, Facultad de Economía. CEDE.

25. Poverty in Colombia. World Bank Country Study. Washington, 1994.

26. Poverty and Inequality - Social Policy

27. http://www.focal.ca/projects/povertyandinequality/socialpolicy/ links_e.asp

28. SÁNCHEZ TRIANA, ERNESTO,. AHMED, KULSUM,. AWE, YEWANDE,. Environmental Priorities and Poverty Reduction: a country environmental analysis for Colombia. Washington, D.C. World Bank, 2007.

29. Sloterdijk, Peter. (2005) Esferas III. Espumas. Ed. Siruela, Barcelona.

30. USAID from the American People: http://gsearch.info.usaid.gov/ search?site=lpa_collection\&entqr $=0 \& u d=1 \&$ sort $=$ date $\% 3 \mathrm{AD} \% 3 \mathrm{AL} \%$ 3Ad1\&output=xml_no_dtd\&oe $=$ UTF-8\&ie $=$ UTF-8\&client=default_fr ontend\&proxystylesheet $=$ default_frontend \&q=poverty

31. Weber, Max (1983). Economía y sociedad, Fondo de Cultura Económica, México. 